\title{
Financial Feasibility Study of Arabica Coffee: A Case Study in Poetete Village, Ermera District, Timor Leste
}

\author{
Mateus Maia de Jesus ${ }^{1 *}$, Lya Aklimawati ${ }^{2)}$, Budi Setiawan ${ }^{3)}$, and Djoko Koestiono ${ }^{3)}$ \\ ${ }^{1)}$ Cooperation Cafe Timor, Rua Barros Gomes 16, Comoro, Dili, Timor Leste \\ ${ }^{2)}$ Indonesian Coffee and Cocoa Research Institute, Jl. PB Sudirman No. 90, Jember, Indonesia \\ ${ }^{3)}$ Faculty of Agriculture, Brawijaya University, Jl. Veteran, Malang, Indonesia \\ ${ }^{*}$ Corresponding author: mateus_maia@ymail.com \\ Received: 13 June 2016/ Accepted: 21 June 2017
}

\begin{abstract}
Coffee is not only the main export product in Timor Leste, but also a source of income for farmer household. The importance of coffee for Timor Leste community should be developed through market oriented farm management on coffee farming. The aim of this research was to analyze financial feasibility of Arabica coffee farming at farmer level; analyze sensitivity of coffee farming toward change in coffee productivity and price; and analyze correlation between productivity with socio-economic characteristics of farmers. This research was carried out at Poetete Village, Ermera Sub-district, Ermera District, Timor Leste. Primary and secondary data were collected in this research. Respondents were selected by stratified random sampling method. Financial feasibility study on coffee farming were analyzed by using Net Present Value (NPV), Internal Rate of Return (IRR) dan Net Benefit Cost Ratio (NBCR). Rank Spearman test was used to analyze the correlation between productivity with variable of production factors and socioeconomic characteristics of farmers. The results showed that Arabica coffee farming was financially feasible to be develop with NPV of USD 205,291,130; IRR of 17.449\%; and Net $\mathrm{B} / \mathrm{C}$ ratio of 2.911 at discount factor $10 \%$. Arabica coffee farming at Poetete Village was classified less responsive toward productivity increasing at $10 \%$ and price decreasing at $10 \%$ with NPV of USD 37,367,151; IRR of $25.95 \%$; and Net B/ $\mathrm{C}$ ratio of 3.862 at discount factor $1 \%$. The correlation between productivity with land ownership (0.965), experience of farmers (0.613), age of farmers (0.663), farmers education level $(0.748)$ and household size $(0.791)$ were categorized as strong to very strong.
\end{abstract}

Keywords: feasibility, financial, sensitivity analysis, coffee, Arabica, Timor Leste

\section{INTRODUCTION}

Organic Arabica coffee is considered as a commodity with high economic value in terms of its contribution to the household income of farmers and national income. This opportunity needs to be utilized to develop the coffee commodity that is oriented to agribusiness and has high competitiveness in the international market. Coffee is not only developed in Indonesia but also expanded to other developing countries such as Timor Leste which is one of developing countries that has a high potential to develop coffee both Arabica and Robusta coffees. Considering the potential of its region, the development of Arabica coffee has a greater opportunity than Robusta coffee, because most areas, particularly the highlands, have developed Arabica coffee either by using monoculture 
or agroforestry system (Deutsh, 2004). The dominance of Arabica coffee development can be seen from its farming area of 53,816 $\mathrm{Ha}$ (Henriques et al.,2012). The cultivation of Arabica coffee in Timor Leste is carried out traditionally since most are managed by smallholders.

The history of coffee development in Timor Leste has begun since the early 1800 s in which it was initially introduced by the Portuguese. In the mid of $19^{\text {th }}$ century, the coffee farming concession was taken over by sandalwood, the largest exporter in Timor Leste (Deutsch, 2004; Henriques et al., 2012). In 1929, coffee growing area was in Fatubesi Village, Hatulia Sub-district, Ermera District. The region was at an altitude of 1,250 $\mathrm{m}$ above sea level. Based on that fact that coffee began to be known and cultivated by rural communities who lived at an altitude of 1,000-2,000 m asl. In general, the community still managed coffee farming subsistently, particularly to meet the household economic needs of farmers (Nevins, 2003; Deutsch, 2004). On the other hand, farmers also have not applied good agricultural practices on their coffee farms, such as weeding, pruning, plant rejuvenation, and others. Under this management, the productivity of coffee in smallholder plantations was still relatively low (Amaral, 2003). Some efforts to increase the productivity can be conducted by establishing cooperation among stakeholders, including farmers, government, private sectors, investors and research institutes/universities, and other parties through the establishment of a coffee-based economic cluster.

The development of coffee in Timor Leste was recorded at 53,806 ha with the Arabica coffee percentage of $86.63 \%$ and the rest $16.37 \%$ of Robusta coffee. These coffee plantations has been spread in six districts, namely Ermera, Liquica, Aileu, Ainaro, Same (Maun-Fahe) and Bobonaro.
According to Sulistyo cit. Hartobudoyo (1985), the land ownership of coffee farmers ranges from 0.5 to $10 \mathrm{ha}$. The area of the land ownership indicated that the coffee farming scale carried out by the farmers was still relatively small and the management was not market oriented. Coffee farming is also a source of household income for farmers. By looking at the coffee management at smallholder level, it is known that farmers generally have a limited capital particularly for developing their farming scale. It has been proved by the behavior of farmers who minimize the use of production factors in their farming activities. In order to develop the coffee farming scale, it is important to know the financial performance of the coffee farming that has been proceeded by the farmers. This will reflect the amount of production costs and benefits received by the farmers. The ultimate goal was to assess the feasibility of the coffee farming at smallholders level. Considering the importance of coffee for farmers, it is necessary to review the business performance and profitability obtained by farmers. Saptana (2008) stated that the assessment of the financial feasibility of farming activities can improve the competitiveness of coffee products. This study was aimed to analyze the financial feasibility of coffee farming at the level of smallholders; to analyze the sensitivity of coffee farming to productivity and price changes, and to analyze the correlation between the productivity of coffee farming and the socio-economic characteristic of farmers.

\section{MATERIALS AND METHODS}

\section{Location, Data, and Sampling}

This research was conducted in Poetete Village, Ermera District in April 2011. The location of research was determined purposively, considering that the village was one 
of the Arabica coffee production regions located in Ermera District. In addition, the pattern of coffee farming was categorized as subsistence farming system, and the technology applied was still traditional. The coffee cultivation in the selected location varied in plant ages, that was more than 10 years. In 2006, the productivity of coffee in Emera was about $184 \mathrm{~kg} / \mathrm{ha}$. Farmers generally sold coffee to various buyers such as the Cooperativa Coffee Timor (CCT), Timor Global, Timor Cooperation, ELSAA Café, NGOs, and others. Furthermore, the buyers export the coffee to various export destinations such as the United States of America, Germany, Portugal, Indonesia, Japan, Australia, and several other importing countries. Most of the coffee is sold with Organic and Fair Trade certification labels to get the premium price by accessing the labeled market (DICA, 2009).

Data were collected by survey method. The method was conducted through direct observation in the field and in-depth interview with the respondents by using questionnaire. The activities were aimed to explore the information of coffee farming at the level of smallholders and simultaneously describing the conditions occuring in the field. The data collected included primary and secondary data. The primary data were obtained through an interview with the farmers regarding farmer characteristic, the use of production factors, production, prices, revenue, and others. The secondary data covered statistical data and articles related to the performance of the coffee sector in Timor Leste. In particular, the data of lending interest rates in Timor Leste were sourced from IndexMundi (2011). The other secondary data such as productivity and market information were traced by accessing information from internet, journals, and related agency reports.
The population being studied was all the coffee farmers located in Poetete Village, Ermera Sub-district, Ermera District. The respondents were determined by using stratified random sampling method because the research population was divided into several groups based on land ownership, farmer age, farmer experience, household size, and farmer education level. The respondents were selected randomly in each group (Christensen et al., 2012; Dhermawan et al., 2012; Wahyuni et al., 2012; Rahardja, 2008; Widyatmini \& Hakim, 2008). The number of respondents taken in each group was $10 \%$ of the respondents representing the population. This method was used because the respondents in the population of this research were homogenous, so grouping the respondents could improve the effectiveness and efficiency in selecting the respondents (Rahardja, 2008).

\section{Analysis Method}

In this research, the feasibility aspect studied was the financial aspect. Therefore, the components that should be considered were the investment cost, production cost, production projection, and benefit on the coffee farming activity. The projection on the cost, production, and benefits should take into account the characteristics of the coffee trees. Regarding of that coffee trees are divided into the phases of immature plants, productive plants and old/less productive plants. This financial feasibility study would use an investment assessment method that considered the time value of money, The coffee farming will assessed by Net Present Value (NPV), Internal Rate of Return (IRR), and Net Benefit Cost Ratio (NBCR). The mathematical equations in each method are outlined as follows (Adiguna et al., 2014; Tiara et al., 2013; Warsika, 2009): 


\section{a. Net Present Value (NPV)}

$$
\begin{aligned}
& N P V=\sum_{t=0}^{n} \frac{R_{t}}{(1+i)^{t}}=\sum_{t=0}^{n} \frac{B_{t}-C_{t}}{(1+i)^{t}} \ldots \ldots \ldots \ldots \ldots \text { (1) } \\
& \text { Notes: } \\
& \mathrm{R}_{\mathrm{t}} \quad: \text { Net cash flow at period- } t \\
& \mathrm{~B}_{\mathrm{t}} \quad: \text { Benefit at year- } t \\
& \mathrm{C}_{\mathrm{t}} \quad: \text { Cost at year- } t \\
& \mathrm{i} \quad: \text { Discount rate } \\
& \mathrm{t} \quad: \text { The time of the cashflow or business period (at year- } t \text { ) } \\
& \mathrm{n} \quad: \text { The duration of farming project or the economic life } \\
& \quad \text { of coffee plants }
\end{aligned}
$$

Assessment of farming investment is divided into three categories, namely: (i) NPV $>0$, meaning that the farming investment is feasible to run; (ii) NPV $<0$, meaning that farming investment does not make profits; (iii) NPV $=0$, meaning that farming investment is at a break-even point.

\section{b. Internal Rate of Return (IRR)}

$$
I R R=i_{1}+\frac{N P V_{1}}{\left(N P V_{1}-N P V_{2}\right)}\left(i_{2}-i_{1}\right)
$$

Notes :

$\mathrm{NPV}_{1}$ : Positive NPV value equal to zero with capital interest of $i_{1}$ percent

$\mathrm{NPV}_{2}$ : Negative NPV value equal to zero with capital interest of $i_{2}$ percent

$i_{1} \quad$ : Discount rate resulting in positive NPV

$i_{2} \quad$ : Discount rate resulting in negative NPV

Assessment of investment is divided into two criteria, namely (i) IRR > the applicable interest rate when investment is executed, meaning that the investment is profitable and feasible to be implemented; and (ii) IRR < interest rate, meaning that the investment is not feasible to run.

c. Net Benefit Cost Ratio (NBCR)

$$
N e t B / C=\frac{\sum_{t=1}^{n} \frac{B_{t}-C_{t}}{(1+i)^{t}}}{\sum_{t=1}^{n} \frac{C_{t}-B_{t}}{(1+i)^{t}}}
$$

Notes:

$\mathrm{B}_{\mathrm{t}} \quad$ : Benefit at year- $t$

$\mathrm{C}_{\mathrm{t}}$ : Cost at year- $t$

Discount rate

Time of a farming project or business period (year- $t$ )

Duration of farming project or economic life of coffee plants
Investment criteria are assessed in two categories, namely (i) the value of $\mathrm{Net} B / \mathrm{C}$ $>1$, meaning that the investment is feasible to be implemented; and (ii) the value of Net $\mathrm{B} / \mathrm{C}<1$, meaning that the investment is not feasible to be implemented.

The sensitivity analysis was conducted to find out the performance of smallholder coffee farming as the result of the changes of productivity and price (Aklimawati \& Hartatri, 2016). Simulation on the sensitivity analysis was $10 \%$ of productivity increase and $10 \%$ of price reduction. This was done to find out the performance of smallholder coffee farming investment to the benefits change. The assessment of the coffee farming investment can be used as a reference for developing coffee commodity and to increase coffee competitiveness in Timor Leste, especially improving the performance of smallholder coffee plantations. It is necessary to be observed because coffee is one of the main export products that contribute to national revenues (Amaral, 2003; Deutsch, 2004).

The correlation analysis was performed to study the correlation between the productivity factor and socio-economic characteristics of farmers. The correlation coefficient between the variables was obtained by Rank Spearman test. This analysis was done by using SPSS Statistic Program Version 15. The socio-economic characteristics of farmers included the variables of land area, farmer experience, farmer age, farmer education level, and house hold size.

\section{RESULTS AND DISCUSSION}

The assessment coffee farming investment, was calculated at discount rates of $10 \%, 15 \%$, and $20 \%$. The results of the financial feasibility of the coffee farming system are presented in Table 1. It was known that NPV value was higher than zero (NPV > $)$ ) at $10 \%$ 
discount rate. It indicated that the capital investment in Arabica coffee plantation would provide a profit (DF 10\%) over the economic life of coffee trees according to the present value. The IRR value at the discount rate of $10 \%$ reached $17.449 \%$, which presented the IRR value was higher than the lending interest rate of $11.04 \%$. The Net B/C ratio was 2.911 at $10 \%$ discount rate, indicating that any present value of the cash out flow of USD 1.00 would provide a benefit of USD 2.911. The results of NPV, IRR, and Net $\mathrm{B} / \mathrm{C}$ ratio at a $10 \%$ discount rate showed that the Arabica coffee plantation management could be considered feasible and profitable to cultivate.

The analysis of NPV, IRR, and Net B/ $\mathrm{C}$ ratio at $15 \%$ discount rate, expressed that the value of its assessment method was decreasing. The NPV value decreased, although the NPV value was still higher than zero (NPV > 0). The value of IRR also decreased to $6.622 \%$, indicating that the IRR value was lower than the lending interest rate. Nevertheless, the value of $\mathrm{Net} B / \mathrm{C}$ ratio reached 1.120 which indicates that the benefit earned amount to USD 1.120 and the cash flow needed is USD 1.00 at present value.

The change of the discount rate at $20 \%$, made the NPV value was positive and higher than zero (NPV > 0). The IRR of this investment was $2.3737 \%$, which means that the management of Arabica coffee plantation had an IRR value below the lending interest rate. The analysis of Net $\mathrm{B} / \mathrm{C}$ ratio gave a result of 1.004, meaning that present value of the cash out flow of USD 1.00 would make a benefit of USD 1.004 .

Based on the three methods of the assessment at $15 \%$ and $20 \%$ discount rate it can be concluded that the management of Arabica coffee plantation in Potete Village, Ermera District, was less feasible to be cultivated and financially less profitable. Looking at the percentage of IRR, this investment had a value below the lending interest rate. Based on these results, business actors will take the initiative to choose a more profitable investment. It occurs while social opportunity cost of capital becomes higher, so the return of its investment cannot cover the social cost during the implementation of investment. In other words, coffee farming does not have the capability to repay capital investment or working capital during its economic life (25 years) (Alam, 2007). The management of Arabica coffee farming in Poetete Village still achieved low profits as a result of less intensive in plant maintenance. Subsistent farming encourage the farmers to minimize the use of production inputs such as fertilizer and labor. Therefore, the productivity of coffee plants has not reached the optimal limit or the productivity is relatively low.

The result of sensitivity analysis showed that the investment on Arabica coffee farming would be analyzed for its sensitivity with the assumption of productivity increase at $10 \%$ and coffee price reduction $10 \%$. Changes were emphasized on the variables that affected the farming revenue for knowing

Table 1. Financial feasibility study on Arabica coffee farming at Poetete Village, Ermera District

\begin{tabular}{ccccc}
\hline \multirow{2}{*}{ Discount factor (\%) } & \multicolumn{3}{c}{ Method of investment analysis } & \multirow{2}{*}{ Result } \\
\cline { 2 - 4 } & NPV (USD) & IRR (\%) & Net B/C Ratio & Feasible \\
10 & $205,291,130$ & 17.449 & 2.911 & Not feasible \\
15 & $104,789,120$ & 6.622 & 1.120 & Not feasible \\
\hline Note: & $72,706,295$ & 2.374 & 1.004 & \\
\hline
\end{tabular}

Note: $\quad$ Lending interest rate in 2011 was $11.04 \%$. 
the production capacity and the selling price that could provide benefits to the farmers. The increase in production costs was considered constant because the management of Arabica coffee farming was still traditional so that the maintenance of the plantation was considered less intensive. Besides, the social cost of capital paid by the farmers on the coffee farm management was decreased to $1 \%$ (DF 1\%). The use of $1 \%$ discount factor rate assumed that the farmers got a loan with a $1 \%$ interest rate to run the farming. Using IRR method on the assessment, it would be compared with the lending interest rate in Timor Leste in 2011 which was up to $11.04 \%$. By knowing this, there were some efforts that could be done to increase the productivity and coffee selling price at the smallholder level. The sensitivity analysis results of the smallholder Arabica coffee farming can be seen in Table 2 .

Based on Table 2, the increased productivity of $10 \%$ at the discount rate of $1 \%$ obtained a positive NPV value which indicated that the Arabica coffee farming was feasible to run because NPV value was higher than zero (NPV > 0). Meanwhile, the IRR value reached $25.95 \%$, indicating that the value exceeded the lending interest rate. The $\mathrm{Net} B / \mathrm{C}$ ratio also showed a value of more than one, that was 3.862 . This indicated that any present value of the cash out flow of USD 1.00 would give a benefit of USD 3.862 . On the other hand, the decreased selling price of $10 \%$, gave the same result as an increased of productivity at $10 \%$, including the values of NPV, IRR and the Net B/C ratio. In general, the Arabica coffee farming was considered feasible to be implemented and able to produce financial benefits despite some changes in production volume and coffee selling price. It could happen wether the benefits forfeited by farmers in running Arabica coffee become lower. In other words, the low opportunity cost of the return on Arabica coffee farming investment will increase the profit earned by the farmers. Nevertheless, the minimum social opportunity cost of capital used for the analysis of coffee farming investment should consider in the amount of cost of capital. The results of the sensitivity analysis showed that Arabica coffee farming in Poetete Village, Ermera District, was less responsive to the changes of $10 \%$ production increase and $10 \%$ price reduction. The assumption of an increase in production and a decrease in the selling price of coffee has not gained a higher financial return to the farmers compared to normal condition. The lack of responsiveness of coffee farming can be seen from the NPV value that was lower than the NPV value under normal conditions at DF $10 \%$. On the other hand, the IRR and Net B/C ratio values became higher using the assumption that a $10 \%$ DF value under normal conditions was reduced to a DF value of $1 \%$.

As an effort to increase coffee productivity at smallholders level, this research also examined the level of correlation between the productivity and socio-economic characteristics of farmers. The strength of the correlation could be known from the value of correlation coefficient on each variable. The correlation coefficient of each variable is presented in Table 3. It can be seen that the correlation coefficient between the productivity and land

Table 2. Sensitivity analysis of Arabica coffee farming at Poetete Village, Ermera Sub-district

\begin{tabular}{lrrrrr}
\hline \multirow{2}{*}{ Assumption } & \multicolumn{2}{c}{ Method of investment analysis } & \multirow{2}{*}{ Result } \\
\cline { 2 - 4 } & NPV (USD) & IRR (\%) & Net B/C Ratio & \\
\hline Constant productivity and prices, DF 10\% & $205,291,130$ & 17.449 & 2.911 & Feasible \\
Productivity increased at 10\% and constant prices, DF 1\% & $37,367,151$ & 25.95 & 3.862 & Feasible \\
Constant productivity and prices decreased at 10\%, DF 1\% & $37,367,151$ & 25.95 & 3.862 & Feasible \\
\hline Note : Lending interest rate in 2011 was 11.04\%. & & &
\end{tabular}


ownership was 0.965 and positive-signed. The value indicated that the productivity had a very close correlation with the area of land ownership. The positive sign of the correlation coefficient indicated that the increasingly widespread coffee land ownership could increase the coffee productivity of the farmers (Mudakir, 2011; Suratiyah, 2015). As one of the production factors, the area of land ownership has an important contribution in farming related to the efficiency of land use for the production process. Increasing land ownership does not mean to make farming efficient. Conversely, relatively small land ownership also does not mean to make farming inefficient. This depends on the management of production factors and the application of the cultivation technology used in farming. Land management, technologies implementation, and allocation of production inputs will affect the level of land productivity, resulting in an increase in the production of coffee plants.

The value of the correlation coefficient between the productivity and farmer experience also showed a strong correlation with a value of 0.613 . In this variable, the correlation coefficient was also marked positive, indicating that the longer the farmer experience in farming activities would have an impact on improving skills and knowledge of farmers. This will encourage farmers to make improvements on the plantation to increase coffee productivity. Mahananto et al. (2009) mentioned that experience is one of the proxy variables of information. In farming, the length of experience relates to the ability of farmers to absorb information on cultivation techniques, marketing, and other technologies. The higher capability of farmers in accumulating the information will affect the behavior of farmers in allocating the production factors to improve coffee plants productivity.

A strong relationship was also shown between the variables of productivity and the farmer age. The correlation coefficient between the two variables was 0.663 and marked a positive value. This indicated that the older age of farmers would increase the farmer experience regarding coffee farming. Increasing the capacity of farmers will bring positive impact in terms of increased productivity because farmers will do more intensive coffee plant maintenance. However, it cannot remain that way because the older the age of farmers will also affect the ability and capacity of farmers in conducting production activities (Mahananto et al., 2009)

The correlation coefficient between the productivity and farmer education level valued at 0.748 , indicating that the correlation between the two variables was strong. The high capacity of farmers in carrying out coffee farming management would result in an increased productivity of their coffee farming. Farmers who have higher education are generally more open to receiving information and innovating new technologies. The level of education will also affect the behavior of farmers in adopting the technologies. Moreover, farmers with higher education will more easily adopt technology to increase production. Farmers can increase their selfcapacity by having a formal or informal education (training, mentoring, etc.) (Kusnadi et al., 2011). It is aimed to increase household income from coffee farming.

Meanwhile, the correlation coefficient between the productivity and the household size of farmers was 0.791 , indicating that the correlation between the two variables was categorized into a strong correlation. The positive value indicated that the greater number of family members could increase the coffee productivity. In that cases, the family members should be a productive labor, resulting in working activities on coffee farming could be handled (Fitriani, 2013) and giving a contribution to the maintenance of coffee plantation. In this condition, the family members are the production 
Table 3. Coefficient of correlation between productivity with socio-economic characteristics of farmers

\begin{tabular}{lccc}
\hline Variable & Coefficient correlation & Probability & Correlation level \\
\cline { 2 - 2 } & Productivity & & Very strong \\
Productivity & 1 & 0.0000 & Strong \\
Land ownership & 0.965 & 0.0000 & Strong \\
Experience of farmer & 0.613 & 0.0000 & Strong \\
Age of farmer & 0.663 & 0.0000 & Strong \\
Farmers education level & 0.748 & 0.0000 & \\
Household size & 0.791 &
\end{tabular}

factor or asset for the farmers whose capability can be utilized to manage coffee farming. Most farmers assume that the use of family labor can save labor costs because they do not need to hire workers from outside the family (Suratiyah, 2015). In addition, farmers will feel more motivated to increase their coffee productivity because the number of family members which is covered is increasingly greater (Purwanti, 2007).

\section{CONCLUSIONS}

Arabica coffee farming in Poetete Village, Ermera District, is financially considered feasible to be cultivated with NPV value of USD 205,291,130; IRR value of 17.449\%; and Net $\mathrm{B} / \mathrm{C}$ ratio of 2.911 at $10 \%$ discount rate. Arabica coffee farming in Poetete Village, Ermera District, is also less responsive to the change of $10 \%$ productivity increase and $10 \%$ selling price reduction with the NPV value of USD $37,367,151$; IRR value of $25.95 \%$; and Net $\mathrm{B} / \mathrm{C}$ ratio value of 3.862 at $1 \%$ discount rate. Meanwhile, the correlation between the coffee productivity and some variables namely land ownership $(0.965)$, farmer experience (0.613), farmer age (0.663), farmer education level (0.748) and household size (0.791) were categorized into a strong to a very strong correlation.

\section{REFERENCES}

Adiguna, R.; L. Sihombing \& Salmiah (2014). Analisis kelayakan investasi pembangunan pabrik minyak kelapa sawit
(PMKS) (Studi kasus Kabupaten Nagan Raya, Provinsi NAD). SocioEconomic of Agriculturre and Agribusiness, 3, 1-15.

Aklimawati, L. \& D.F.S. Hartatri (2016). Investasi pada bisnis kopi. p. 824-848. In: KOPI: Sejarah, Botani, Proses Produksi, Pengolahan, Produk Hilir, dan Sistem Kemitraan. Gadjah Mada University Press. Yogyakarta, Indonesia.

Alam, S. (2007). Kelayakan pengembangan kopi sebagai komoditas unggulan di Provinsi Sulawesi Selatan. Socio-Economic of Agriculturre and Agribusiness, 7, 1-14.

Amaral, F.E. (2003). Prospects for coffee development in Timor Leste. ACIAR Proceedings No. 113 Agriculture: New Directions for a New Nation Timor Leste (TimorLeste), p. 24-27. Dili, Timor Leste.

Christensen, A.I.; O. Ekholm; C. Glümer; A.H. Andreasen; M.F. Hvidberg; P.L. Kristensen; F.B. Larsen; B. Ortiz \& K. Juel (2012). The danish national health survey 2010: Study design and respondent characteristics. Scandinavian Journal of Public Health, 40, 391-397.

Dhermawan, A.A.N.B.; I.G.A. Sudibya \& I.W.M. Utama (2012). Pengaruh motivasi, lingkungan kerja, kompetensi dan kompensasi terhadap kepuasan kerja dan kinerja pegawai di lingkungan kantor Dinas Pekerjaan Umum Provinsi Bali. Jurnal Manajemen, Strategi Bisnis, dan Kewirausahaan, 6, 173-184.

DICA (2009). Coffee. Commodity Profile Series, No. 9, Version 1, Edition July 2009. Directorate of Industrial Crops and Agribusiness, Ministry of Agriculture and Fisheries, Timor Leste. 
Deutsch, C. (2004). Overview of the Coffee Sector in Timor-Leste. Oxfam, Dili.

Fitriani; Sutarni \& L. Irawati (2013). Faktorfaktor yang mempengaruhi produksi, curahan kerja, dan konsumsi petani tebu rakyat di Propinsi Lampung. ESAI, 7, 1-11.

Hartobudoyo (1985). Laporan Survei dan Perbaikan Potensi Perkebunan Kopi Timor-Timur. Balai Penelitian dan Pengembangan Pertanian, Departemen Pertanian, Jakarta.

Henriques, P.D.; M.R. Lucas; M.L.D.S. Carvalho \& C.D.C.D. Deus (2012). Coffee value chain in Timor-Leste. p. 503-528. In: J. Briz. \& I. de Felipe (Eds). Food Value Chains Network in the $21^{\text {st }}$ Century: Challenges and Opportunities from an International View. Portugal.

IndexMundi (2011). Timor Leste: Green Coffee by Year. IndexMundi, 520 Chinley $\mathrm{Ct}$, Charlotte, USA.

Kusnadi, N.; N. Tinaprilla; S.H. Susilowaty \& A. Purwoto (2011). Analisis efisiensi usahatani padi di beberapa sentra produksi padi di Indonesia. Jurnal Agro Ekonomi, 29, 25-48.

Mahananto; S. Sutrisno \& C.F. Ananda (2009). Faktor-faktor yang mempengaruhi produksi padi: Studi kasus di Kecamatan Nogosari, Boyolali, Jawa Tengah. WACANA, 12, 179-191.

Mudakir, B. (2011). Produktivitas lahan dan distribusi pendapatan berdasarkan status penguasaan lahan pada usahatani padi (kasus di Kabupaten Kendal Propinsi Jawa Tengah). Jurnal Dinamika Ekonomi Pembangunan, 1, 74-83.

Nevins, J. (2003). Restitution over coffee: truth, reconciliation, and environmental violence in Timor Leste. Political Geography, 22, 677-701.
Purwanti, R. (2007). Pendapatan petani dataran tinggi SUB DAS Malino (Studi kasus: Kelurahan Gantarang, Kabupaten Gowa). Jurnal Penelitian Sosial dan Ekonomi Kehutanan, 4, 257-269.

Raharja, S. (2008). Studi empiris mengenai penerapan metode sampling audit dan faktor-faktor yang mempengaruhi penggunaan metode sampling audit oleh auditor BPK. Jurnal Bisnis dan Ekonomi, 15, 54-66.

Saptana (2008). Keunggulan komparatifkompetitif dan strategi kemitraan. Socio-Economic of Agriculture and Agribusiness, 8, 1-26.

Suratiyah, K. (2015). Ilmu Usahatani (Edisi Revisi). Penebar Swadaya: Jakarta.

Tiara, M.D.; S. Supardi \& J. Sutrisno (2013). Analisis investasi konversi komoditas kopi ke karet di PT. Perkebunan Nusantara IX (Persero) Kebun Batujamus/ Kerjoarum Afdeling Karanggadungan Kabupaten Karanganyar. Agribusiness Review, 1, 78-89.

Wahyuni, S.S.; S.P. Utama \& G. Mulyasari (2012). Analisis kelayakan finansial usahatani kopi Arabika di Desa Bandung Baru Kecamatan Kabawetan Kabupaten Kepahiang. AGRISEP, 11, 43-50.

Warsika, P.D. (2009). Studi kelayakan investasi bisnis properti (Studi kasus : Ciater Riung Rangga). Jurnal Ilmiah Teknik Sipil, 13, 32-38.

Widyatmini \& L. Hakim (2008). Hubungan kepemimpinan, kompensasi dan kompetensi terhadap kinerja pegawai Dinas Kesehatan Kota Depok. Jurnal Ekonomi Bisnis, 2, 163-171.

$$
* * 0 * *
$$


de Jesus et al. 